\title{
Hubungan Antara Perceived Organizational Support Dengan Kinerja Karyawan Bidang Produksi Di Pt Batanghari Barisan Padang
}

\author{
Zurriyati, Krisnova Nastasia, Ria Okfrima \\ Fakultas Psikologi, Universitas Putra Indonesia "YPTK" Padang, Indonesia \\ Email: zurriyati01@gmail.com, krisnovanastasia32@gmail.com
}

\begin{abstract}
This study aims to determine the relationship between perceived organizational support and employee performance in production at PT Batanghari Barisan Padang. The independent variable in this study is perceived organizational support and the dependent variable is Performance. The measuring instrument used in this study is the scale of perceived organizational support and performance. The sampling technique in this study uses a saturated sample technique. The sample in this study was 81 employees of the production field of PT Batanghari Barisan Padang. The validity and reliability test in this study uses the Cronbach Alpha technique. The results of the validity coefficient on the scale of perceived organizational support move from rix $=0.310$ to rix $=0.809$ with a reliability coefficient of $\alpha=0.883$ while on the scale of moving performance from rix $=0.316$ to rix $=0.803$ with a reliability coefficient of $\alpha=0.864$. Based on data analysis, a correlation value of 0.515 was obtained with a significance level of 0.000 , which means the hypothesis was accepted. This shows that there is a significant relationship between perceived organizational support and the performance of employees in the production sector at PT Batanghari Barisan Padang. The effective contribution of the variable perceived organizational support for performance by $30 \%$.
\end{abstract}

Keywords: perceived organizational support, performance, employees.

\begin{abstract}
Abstrak
Penelitian ini bertujuan untuk mengetahui hubungan antara perceived organizational support dengan kinerja karyawan di PT Batanghari Barisan Padang. Variabel bebas dalam penelitian ini adalah perceived organizational support dan variabel terikat adalah Kinerja. Alat ukur yang digunakan dalam penelitian ini adalah skala perceived organizational support dan kinerja. Teknik pengambilan sampel dalam penelitian ini menggunakan teknik sampel jenuh. Sampel dalam penelitian ini adalah 81 orang karyawan PT Batanghari Barisan Padang. Uji validitas dan reliabilitas pada penelitian ini menggunakan teknik Alpha Cronbach. Hasil koefisien validitas pada skala perceived organizational support bergerak dari $\mathrm{rix}=0,310$ sampai dengan $\mathrm{rix}=$ 0,809 dengan koefisien reliabilitas sebesar $\alpha=0,883$ sedangkan pada skala kinerja bergerak dari rix $=0,316$ sampai dengan rix $=0,803$ dengan koefisien reliabilitas sebesar $\alpha=0,864$. Berdasarkan analisis data, diperoleh nilai korelasi sebesar 0,515 dengan taraf signifikansi 0,000 yang berarti hipotesis diterima. Hal ini menunjukkan bahwa ada hubungan yang signifikan antara antara perceived organizational support dengan kinerja karyawan di PT Batanghari Barisan Padang. Adapun sumbangan efektif dari variabel perceived organizational Support terhadap kinerja sebesar $30 \%$.
\end{abstract}

Kata Kunci: perceived organizational support, kinerja, karyawan.

\section{Pendahuluan}

Sumber daya manusia merupakan faktor sentral dalam pengelolaan suatu organisasi dalam mencapai tujuannya, karena suatu organisasi memerlukan sumber daya manusia sebagai pengelola sistem dalam organisasi. Sumber daya manusia yang berkompeten dengan kinerja yang baik dapat menunjang keberhasilan bisnis dan juga sebaliknya, sumber daya manusia yang tidak berkompeten serta kinerjanya yang buruk dalam menimbulkan masalah kompetitif yang dapat membuat perusahaan berada dalam kondisi yang merugi, sehingga sistem yang berjalan harus memperhatikan beberapa aspek penting seperti kepemimpinan, motivasi, lingkungan kerja, kinerja dan aspek-aspek lainnya, hal ini akan menjadikan manajemen sumber daya manusia sebagai salah satu indikator penting pencapaian tujuan organisasi secara efektif dan efisien. (Potu, 2013). Sumber daya manusia yang berkualitas dan kompetitif sangat berkaitan erat dengan kinerja pegawai di dalam organisasi, akan tetapi dalam pelaksanaannya sumber daya manusia dalam organisasi penuh dengan keterbatasan. Beberapa permasalah terdapat pada kesadaran akan tugas dan tanggung jawab individu terhadap tugas pokok dan fungsi dari masing-masing individu dalam organisasi, sehingga haruslah ada upaya dari organisasi untuk meningkatkan kinerja pegawai untuk mencapai tujuan organisasi. Perilaku yang menjadi tuntutan organisasi saat ini tidak hanya perilaku in-role yaitu melaksanakan pekerjaan sesuai dengan 
yang ada dalam job descrition, tetapi juga perilaku extra-role yang di mana kontribusi peran extra untuk menyelesaikan pekerjaan dari organisasi (Aswin dan Rahyuda, 2017). Kinerja adalah sesuatu yang dicapai atau prestasi yang diperlihatkan atau kemampuan bekerja, dengan kata lain bahwa kinerja dapat diartikan sebagai prestasi kerja. Penilaian kinerja adalah alat yang berfaedah tidak hanya untuk mengevaluasi kerja dari para karyawan, tetapi juga untuk mengembangkan dan memotivasi kalangan karyawan Simamora (dalam Sukarjati dkk, 2016). Perusahaan yang dapat bertahan membutuhkan karyawan memiliki kinerja yang dapat membuat tujuan-tujuan perusahaan tercapai, baik itu dalam organisasi pemerintahan maupun swasta dalam mencapai tujuan yang telah ditetapkan melalui kegiatan-kegiatan yang digerakkan oleh orang atau sekelompok orang yang bekerja sama yang berperan aktif sebagai pelaku dalam menghasilkan kinerja organisasi yang baik. Dengan kata lain, tercapainya tujuan organisasi dikarenakan adanya upaya yang dilakukan oleh orang-orang dalam organisasi tersebut. Kinerja organisasi sangat ditentukan oleh unsur karyawan atau pegawainya, karena itu dalam mengukur kinerja organisasi biasanya diukur dari tampilan kerja karyawannya. Kinerja yang baik akan berdampak pada kinerja organisasi secara keseluruhan, yang pada akhirnya dapat terlihat dari pencapaian organisasi (Genisa dkk, 2018). Keberhasilan organisasi dipengaruhi oleh kinerja individu karyawan sehingga setiap organisasi berupaya mengelola sumber daya manusia yang dimiliki. Penting bagi organisasi mengetahui faktor yang dapat memengaruhi kinerja karyawan, salah satunya melalui persepsi dukungan organisasi atau perceived organizational support (POS) (Ariarni dan Afrianty, 2017). Perceived organization support (POS) didefinisikan sebagai kepercayaan karyawan bahwa organisasi menghargai kontribusi dan kesejahteraan mereka. Teori dukungan organisasi beranggapan bahwa untuk menentukan kesiapan organisasi memberikan reward atas peningkatan kinerja dan memenuhi kebutuhan sosioemosional, karyawan mengembangkan kepercayaan bahwa organisasi menghargai kontribusi dan memperhatikan kesejahteraan mereka. Perceived organizational support (POS) juga dinilai sebagai jaminan bahwa organisasi akan menyediakan bantuan untuk menyelesaikan sebuah tugas secara efektif dan saat menghadapi kondisi penuh dengan stres Rhoades \& Eisenberger (dalam Man dan Hadi, 2013). Berdasarkan hasil observasi dan wawancara yang dilakukan peneliti pada tanggal 22 April 2019, PT. Batanghari Barisan (BHB) bergerak pada bidang pengolahan bahan baku getah karet, yang mana karet tersebut diolah menjadi setengah jadi. PT. Batanghari Barisan (BHB) memproduksi satu jenis produk, yaitu produk SIR.20 dengan total produksi mencapai 25.000 ton per tahun. Produk SIR.20 tersebut dipasarkan ke negara produksi ban seperti Jepang, Eropa, dan Amerika, banyaknya kontrak terkadang membuat para tenaga kerja menjadi kewalahan belum lagi disaat cuaca musim hujan membuat karet yang harusnya cepat kering menjadi lama. Pengolahan dilakukan setiap hari, dari hari senin hingga sabtu mulai jam 07:0015:00 WIB, jika banyaknya pesanan atau kontrak yang masuk hari minggu juga melakukan pengolahan, dan juga lumayan sering kontrak melebihi target sehingga para karyawan sering lembur melakukan pengolahan di hari minggu. Karet yang dihasilhkan per harinya mencapai 80 ton perhari. Karet yang dihasilkan terkadang sesuai kriteria lebih kurang mencapai penilaian $80 \%$ jika tidak banyak pesanan atau kontrak yang masuk, tetapi terkadang banyak juga karet yang dihasilkan tidak sesuai kriteria hal ini disebabkan banyaknya kendala pada kinerja karyawannya, misalnya disaat banyaknya pesanan atau kontrak yang masuk bahan baku tidak terlalu disaring karena membutuhkan banyak bahan baku untuk menghasilkan banyak produk, dan disaat barang sudah jadi disitulah ketahuan hasil tidak sesuai dengan kriteria, ini menyebabkan turunnya kualitas dari produk-produk yang dihasilkan. Walaupun lingkungan pekerjaan dilengkapi oleh CCTV tetapi masih saja ada pekerjaan karyawan yang banyak menyalahi aturan, hal ini dikarenakan kurangnya pengawasan dari atasan kebawahan menyebabkan banyak peluang menghasilkan produk-produk yang tidak sesuai kriteria. Padahal suatu perusahaan bahan baku harus melakukan pengawasan yang ketat untuk menghasilkan kualitas produk yang baik dan sesuai kriteria standar.

\subsection{Kinerja}

Kinerja adalah hasil kerja secara kualitas dan kuantitas yang dicapai oleh seorang pegawai dalam melaksanakan tugasnya sesuai dengan tanggung jawab yang diberikan kepadanya menurut Mangkunegara (dalam Kumara dan Utama, 2016). Kinerja dalam organisasi merupakan jawaban dari berhasil atau tidaknya tujuan organisasi yang telah ditetapkan. Kinerja seorang karyawan merupakan hal yang bersifat individual, karena setiap karyawan mempunyai tingkat kemampuan yang berbeda beda dalam mengerjakan tugasnya. Kinerja karyawan dapat ditingkatkan dengan memberikan contoh 
yang baik dari seorang pemimpin, memotivasi karyawan dan selalu memperhatikan karyawan dalam bekerja (Potu, 2013). Kinerja merupakan perilaku nyata yang ditampilkan setiap orang sebagai prestasi kerja yang dihasilkan karyawan sesuai dengan perannya dalam perusahaan menurut Gaol (dalam Ariarni dan Afrianty, 2017). Setiap perusahaan menginginkan kinerja karyawannya yang bagus, untuk itu karyawan dituntut untuk meningkatkan kinerja guna membantu perusahaan dalam mengembangkan produktiftas guna mencapai tujuan perusahaan (Arifin dkk, 2014).

\subsection{Aspek-Aspek Kinerja}

Menurut Minner (dalam Sutrisno, 2010) mengemukakan secara umum dapat dinyatakan empat aspek dari kinerja, yaitu :mengemukakan bahwa terdapat tiga aspek dari burnout yaitu: (a) kualitas, menerangkan tentang jumlah kesalahan, waktu, dan ketepatan dalam melakukan tugas (b) kuantitas, berkenaan dengan berapa jumlah produk atau jasa yang dapat dihasilkan (c) waktu kerja, menerangkan akan berapa jumlah absen, keterlambatan, serta masa kerja yang telah dijalani individu pegawai tersebut (d) kerja sama, menerangkan akan bagaimana individu membantu atau menghambat usaha dari teman sekerjanya.

\subsection{Perceived Organizational Support}

Grace (dalam Putra dan Sriathi, 2017). menyatakan perceived organizational support (POS) merupakan kepercayaan dari karyawan tentang bagaimana organisasi menghargai segala kontribusi maupun kesejahteraan mereka. Perceived organizational support (POS) yang meningkat akan membuat para karyawan merasa memiliki kewajiban penting untuk selalu berkontribusi dan peduli mengenai kesejahteraan maupun tujuan organisasi. Cahyana (dalam Putra dan Rahyuda, 2016) menyatakan bahwa apabila suatu perusahaan ingin mempertahankan dan meningkatkan retensi karyawannya, maka perusahaan nantinya perlu meningkatkan perceived organizational support (POS).

\subsection{Aspek-Aspek Perceived Organizational Support}

Aspek-aspek Perceived Organizational Support menurut Allen \& Brady (dalam Sahrah, 2017) yaitu: (a) sikap organisasi terhadap ide-ide karyawan, bila organisasi dinilai oleh karyawan, dapat melihat atau menghargai ide-ide karyawannya, maka POS menjadi positif. Sebaliknya, POS akan menjadi negatif bila perusahaan selalu menolak ide dari karyawan dan segala sesuatu merupakan keputusan dari manajemen tertinggi (b) ikap organisasi terhadap karyawan yang mengalami masalah, bila organisasi dinilai tidak memperlihatkan usaha untuk membantu karyawan yang sedang terlibat masalah. Hal ini akan menyebabkan karyawan melihat tidak ada dukungan yang diberikan organisasi terhadap karyawan yang bersangkutan (c) sikap organisasi terhadap kesejahteraan dan kesehatan karyawan, POS disebut tinggi, jika karyawan melihat bahwa organisasi memberikan dukungan agar setiap orang dapat bekerja secara optimal demi tercapainya tujuan bersama.

\section{Metode Penelitian}

Jenis penelitian ini adalah kuantitatif korelasional dengan variabel penelitian Menurut Sugiyono (2014) variabel Dependen, penelitian Kinerja Karyawan (Y) dan Variabel Independen, Perceived Organizational Support (X). Populasi pada penelitian ini adalah karyawan bagian produksi PT. Batanghari Barisan Padang yang berjumlah 81 orang. Teknik pengambilan sampel dalam penelitian ini adalah sampling jenuh yaitu teknik penentuan sampel bila semua anggota populasi digunakan sebagai sampel. Alat ukur yang digunakan dalam penelitian ini adalah skala Perceived Organizational Support dan Kinerja Karyawan. Menurut Azwar (2014) skala merupakan perangkat pertanyaan yang disusun untuk mengungkap atribut tertentu melalui respon terhadap pertanyaan tersebut. Skala dalam penelitian ini memiliki format respon dengan empat alternatif jawaban. Skala yang digunakan dalam penelitian ini menggunakan format respon jawaban model Likert, yaitu suatu metode pernyataan sikap yang menggunakan respon subjek sebagai penentu nilai skalanya yang telah dimodifikasi menjadi empat alternatif jawaban dan aitem-aitem dalam skala ini dikelompokkan dalam aitem favorable dan unfavorable. Bentuk skala yang digunakan untuk mengukur intensi prososial dan skala kepuasan pengguna menggunakan empat alternatif jawaban, yaitu SS (Sangat Setuju), S (Setuju), TS (Tidak Setuju), dan STS (Sangat Tidak Setuju). Skala penelitian akan melewati berbagai tahap analisis yaitu 
uji normalitas digunakanuntuk mengetahui apakah populasi data terdistribusi normal atau tidak. Uji normalitas menggunakan uji kolmogorov-Smirnov. Uji linearitas bertujuan untuk mengetahui apakah dua variabel mempunyai hubungan yang linear atau tidak. Dua variabel dikatakan mempunyai hubungan yang linear bila signifikasi (linearty) kurang dari 0,05 . Selain itu dilakukan uji Validitas, sejauh mana ketepatan dan kecermatan suatu alat ukur dalam melakukan fungsi ukurnya (Azwar, 2014). Suatu item dapat dianggap memiliki daya diskriminasi yang memuaskan jika berkorelasi signifikan terhadap skor total atau jika melakukan penilaian langsung terhadap koefisien korelasi bisa digunakan batas nilai berkriteria rxy $\geq 0,3$ (Priyatno, 2013). Data skala dikatakan memiliki daya beda tinggi jika koefisien korelasi lebih besar atau sama dengan 0,3 ( $r x y \geq 0,3$ ) dan sebaliknya aitem skala dikatakan gugur jika koefisien korelasi lebih kecil dari 0,3 ( $\mathrm{rxy} \geq 0,3)$.

\section{Hasil dan Pembahasan}

Peneliti menyebarkan 81 skala Perceived Organizational Support dan skala Kinerja Karyawan dan meminta kesediaan kepada karyawan tersebut untuk mengisi skala kemudian menjelaskan cara pengisian skala dengan cara memberikan skala secara langsung kepada karyawan bagian produksi PT. Batanghari Barisan Padang. Sebelum pengisian skala dilakukan, peneliti terlebih dahulu memberitahukan petunjuk pengisian dengan singkat dan jelas.

\subsection{Hasil}

Koefisien Validitas skala Perceived Organizational Support dengan nilai corrected item-total correlation berkisar antara 0,310 sampai dengan 0,809, dengan reabilitas 0,883 , validitas skala Kinerja Karyawan dengan nilai corrected item-total correlation berkisar antara 0,316 sampai dengan 0,803 , dengan reabilitas 0,864. Uji normalitas dalam penelitian ini menggunakan uji KolmogorovSmirnov. Priyatno (2013) menyatakan bahwa data yang dinyatakan berdistribusi normal jika signifikansi (p) lebih besar dari 0,05. Berdasarkan hasil pengolahan data dengan menggunakan program IBM SPSS 21.0, Maka diperoleh hasil sebagai berikut:

Tabel 1. Uji Normalitas Skala Perceived Organizatinal Support dengan Kinerja Karyawan

\begin{tabular}{ccccc}
\hline \multicolumn{4}{c}{ Tabel 1. Uji Normalitas Skala Perceived Organizatinal Support } & dengan Kinerja Karyawan \\
\hline Variabel & N & KSZ & P & Sebaran \\
\hline $\begin{array}{c}\text { Perceived Organizational } \\
\text { Support }\end{array}$ & 81 & 1,011 & 0,259 & Normal \\
Kinerja Karyawan & 81 & 1,094 & 0,182 & Normal \\
\hline
\end{tabular}

Nilai signifikansi pada skala Perceived Oranizational Support sebesar $\mathrm{p}=0,259$ dengan KSZ $=1,011$ hasil tersebut menunjukan bahwa nilai p > 0,05, artinya sebaran skala Perceived Organizational Support terdistribusi secara normal, sedangkan untuk skala Kinerja Karyawam diperoleh nilai signifikansi sebesar $\mathrm{p}=0,182$ dengan $\mathrm{KSZ}=1,094$ hasil tersebut menunjukan bahwa nilai $\mathrm{p}>0,05$, artinya sebaran terdistribusi secara normal. Selanjutnya uji linearitas dapat dilihat pada tabel 2 berikut:

Tabel 2. Uji Linieritas Perceived Organizational Support dengan Kinerja Karyawan

\begin{tabular}{ccccc}
\hline $\mathbf{N}$ & Df & Mean Square & F & Sig \\
\hline 81 & 1 & 27,325 & 6,425 & 0,013 \\
\hline
\end{tabular}

Berdasarkan tabel diatas, diperoleh nilai $F=6,425$ dengan signifikansi sebesar $p=0,013$ dengan ketentuan $(\mathrm{p}<0,05)$, artinya varian pada skala Perceived Organizational Support dan Kinerja Karyawan tergolong linier.

Tabel 3. Hasil Uji Korelasi Antara Perceived Organizational Support dengan Kinerja Karyawan

\begin{tabular}{ccccc}
\hline $\mathbf{P}$ & $(\boldsymbol{\alpha})$ & Nilai Korelasi $(\mathbf{r})$ & R square & Kesimpulan \\
\hline 0,000 & 0.01 & 0,515 & 0,256 & $\begin{array}{c}\text { sig (2-tailed) } 0,000<0,01 \text { level of } \\
\text { significant }(\alpha), \text { berarti hipotesis } \\
\text { diterima. }\end{array}$ \\
\hline
\end{tabular}

Berdasarkan tabel di atas, maka diperoleh koefisien korelasi antara variabel Perceived Organizational Support dengan Kinerja Karyawan yaitu sebesar $r=0,515$ dengan taraf signifikansi $\mathrm{p}=0,000$. Hal ini menunjukkan adanya korelasi yang kuat dan berarah positif atau searah antara kedua variabel tersebut, 
yang artinya jika semakin tinggi Perceived Organizational Support, maka semakin tinggi Kinerja Karyawan, sebaliknya jika semakin rendah Perceived Organizational Support, maka semakin rendah Kinerja Karyawan. Hal ini diperkuat dengan hasil uji signifikansi dengan bantuan IBM SPSS versi 21.0, didapatkan $\mathrm{p}=0,000<0,01$ level of significant $(\alpha)$, artinya hipotesis diterima, bahwa terdapat hubungan antara Perceived Organizational Support dengan Kinerja Karyawan di PT. Batanghari Basrisan Kota Padang.

Tabel 4. Descriptive Statistic

\begin{tabular}{cccccc}
\hline Variabel & N & Mean & Std. Deviation & Minimum & Maximum \\
\hline Perceived & 81 & 63,36 & 2,521 & 58 & 68 \\
Organizational Support & 81 & 80,56 & 3,592 & 73 & 87 \\
Kinerja Karyawan & 81 & & & \\
\hline
\end{tabular}

Berdasarkan nilai mean hipotetik, maka dapat dilakukan pengelompokkan yang mengacu pada kriteria pengkategorisasian dengan tujuan menempatkan individu kedalam kelompok-kelompok yang terpisah secara berjenjang menurut suatu kontinum berdasarkan atribut yang diukur (Azwar, 2012) berdasarkan norma kategorisasi, diperoleh kategorisasi subjek penelitian pada variabel, Perceived Organizational Support Dan Kinerja Karyawan sebagai berikut :

Tabel 5. Kategori Perceived Organizational Support dengan Kinerja Karyawan

\begin{tabular}{ccccc}
\hline Variabel & Skor & Jumlah & Persentase (\%) & Kategori \\
\hline \multirow{2}{*}{ Perceived Organizational } & $56-60$ & 8 & $10 \%$ & Rendah \\
Support & $61-65$ & 54 & $67 \%$ & Sedang \\
& $66-68$ & 19 & $23 \%$ & Tinggi \\
Kinerja Karyawan & $73-75$ & 4 & $5 \%$ & Rendah \\
& $76-84$ & 65 & $80 \%$ & Sedang \\
& $85-87$ & 12 & $15 \%$ & Tinggi \\
\hline
\end{tabular}

Berdasarkan tabel di atas, maka dapat diperoleh gambaran bahwa sebesar $10 \%$ Perceived Organizational Support pada kategori rendah, 67\% Perceived Organizational Support pada kategori sedang, dan 23\% Perceived Organizational Support pada kategori tinggi, sedangkan untuk variabel Kinerja Karyawan diperoleh gambaran bahwa sebesar 5\% karyawan memiliki kinerja dengan kategori rendah, $80 \%$ karyawan memiliki kinerja dengan kategori sedang, dan 15\% karyawan memiliki kinerja dengan kategori tinggi.

Besar sumbangan variabel Perceived Organizational Support terhadap variabel Kinerja Karyawan dapat ditentukan dengan menggunakan rumus koefisien determinan. Koefisien determinan adalah kuadrat dari koefisien korelasi yang dikali dengan 100\%. Adapun besar sumbangan efektif ( $R$ square) dari variabel Perceived Organizational Support terhadap Kinerja Karyawan adalah sebesar 30\% artinya Perceived Organizational Support memiliki sumbangan sebesar 30\% terhadap Kinerja Karyawan sedangkan $70 \%$ dipengaruhi oleh faktor lain seperti kondisi fisik individu, kondisi psikologis individu dan factor eksternal seperti gaya hidup.

\subsection{Pembahasan}

Berdasarkan hasil uji korelasi Product Moment (Pearson) yang dilakukan dengan bantuan IBM SPSS 21.0, dimana level of significant $(\alpha)$ 0,01 dan diperoleh nilai koefisien korelasi $\left(\mathrm{r}_{\mathrm{xy}}\right)=0,515$ dengan nilai (p) sig $=0,000$, karena nilai (p) sig $0,000<0,01$ maka hipotesis diterima. Hasil ini menunjukkan bahwa terdapat hubungan antara Perceived Organizational Support dengan Kinerja Karyawan pada karyawan PT. Batanghari Barisan Kota Padang dengan arah positif. Artinya jika Perceived Organizational Support tinggi, maka Kinerja Karyawan pada Karyawan PT. Batanghari Barisan Kota Padang juga akan tinggi, sebaliknya jika Perceived Organizational Support rendah, maka Kinerja Karyawan PT. Batanghari Barisan Kota Padang juga akan semakin rendah.

Organisasi harus percaya bahwa untuk mencapai keunggulannya, perlu mengusahakan kinerja individu yang setinggi-tingginya. Pada dasarnya kinerja individu mempengaruhi kinerja tim dan pada akhirnya mempengaruhi kinerja organisasi secara keseluruhan. Perilaku yang menjadi tuntutan organisasi tidak hanya perilaku in-role tetapi juga perilaku extra-role. Perilaku extra-role sangat 
penting artinya karena memberikan manfaat yang lebih baik untuk menunjang keberlangsungan organisasi Oguz (dalam Fitriastuti, 2013).

Keberhasilan organisasi dipengaruhi oleh kinerja individu karyawan sehingga setiap organisasi berupaya mengelola sumber daya manusia yang dimiliki. Penting bagi organisasi mengetahui faktor yang dapat memengaruhi kinerja karyawan, salah satunya melalui persepsi dukungan organisasi atau perceived organizational support (POS) (Ariarni dan Afrianty, 2017).

Perceived organization support (POS) didefinisikan sebagai kepercayaan karyawan bahwa organisasi menghargai kontribusi dan kesejahteraan mereka. Teori dukungan organisasi beranggapan bahwa untuk menentukan kesiapan organisasi memberikan reward atas peningkatan kinerja dan memenuhi kebutuhan sosioemosional, karyawan mengembangkan kepercayaan bahwa organisasi menghargai kontribusi dan memperhatikan kesejahteraan mereka. Perceived organizational support (POS) juga dinilai sebagai jaminan bahwa organisasi akan menyediakan bantuan untuk menyelesaikan sebuah tugas secara efektif dan saat menghadapi kondisi penuh dengan stres Rhoades \& Eisenberger (dalam Man dan Hadi, 2013).

Adapun sumbangan efektif dari variabel Perceived organizational support terhadap Kinerja Karyawan sebesar 30\%, hal ini dapat diartikan bahwa Perceived organizational support mampu memberikan kontribusi positif terhadap Kinerja Karyawan, sedangkan 70\% sisanya dipengaruhi oleh faktor-faktor lain. Adapun faktor lainnya, seperti faktor internal sepeprti kondisi fisik individu, kondisi psikologis individu dan faktor eksternal seperti gaya hidup.

\section{Kesimpulan}

Berdasarkan hasil analisis data yang telah dilakukan oleh peneliti, maka dapat ditarik kesimpulan yang sekaligus merupakan jawaban dari tujuan penelitian adalah sebagai berikut : terdapat hubungan yang signifikan antara Perceived organizational support dengan Kinerja Karyawan pada Karyawan PT. Batanghari Barisan Kota Padang. Hubungan antara kedua variabel tersebut positif yang artinya semakin tinggi Perceived organizational support maka semakin tinggi Kinerja Karyawan dan sebaliknya semakin rendah Perceived organizational support maka semakin rendah Kinerja Karyawan, hal ini berarti hipotesis diterima.

\section{Daftar Rujukan}

Ariarni \& Afrianty. (2017). pengaruh perceived organizational support terhadap kinerja karyawan dengan employee engagement sebagai variabel intervening. Vol.50 No.4. Universitas Brawijaya

Arifin, dkk. (2014). pengaruh pemberdayaan dan motivasi terhadap kinerja karyawan. Vol.8 No.2. Universitas Brawijaya.

Aswin \& Rahyuda. (2017). Pengaruh Perceived Organizational Support Terhadap Organizational Citizenship Behavior Dengan Variabel Kepuasan Kerja Sebagai Mediasi. Vol.6 No.5. Fakultas Ekonomi dan Bisnis Universitas Udayana Bali.

Azwar, Saifuddin. (2016). Penyusunan Skala Psikologi. Yogyakarta: Pustaka Pelajar.

Dwitasari, dkk. (2015). pengaruh perceived organizational support dan organizational-based self esteem terhadap work engagement. Vol.1 No.1. Universitas Brawijaya.

Fitriastuti, Triana. (2013). Pengaruh Kecerdasan Emosional, Komitmen Organisasional dan Organizational Citizenship Behavior Terhadap Kinerja Karyawan. Vol.4 No.2. Fakultas Ekonomi Universitas Mulawarman.

Genisa, dkk. (2018). Hubungan Antara Adversity Quotient Dengan Kinerja Pada Pegawai di Dinas Pariwisata Kebudayaan dan Pemuda dan Olahraga Kabupaten Kerinci. Fakultas Psikologi Universitas Putra Indonesia "YPTK" Padang.

Kumara \& Utama. (2016). pengaruh pelatihan terhadap kinerja karyawan dengan mediasi kepemimpinan pada hotel satriya cottages kuta-bali. Vol.5 No.3. Universitas Udayana.

Man \& Hadi. (2013). Hubungan antara Perceived Organizational Support dengan Work Engagement Pada Guru SMA Swasta di Surabaya. Vol.2 No.2.

Mursidta, Silviana. (2017). Pengaruh Perceived Organizational Support (Persepsi Dukungan Organisasi) dan Kepuasan Kerja Terhadap Kinerja Karyawan Pada PT. Varia Usaha Beton Gresik. Vol.5 No.1. Universitas Negeri Surabaya.

Murniasih \& Sudarma. (2016). Pengaruh Persepsi Dukungan Organisasi dan Kompetensi Pada Kinerja Karyawan Dimediasi Komitmen Afektif. Universitas Negeri Semarang. 
Potu, Aurelia. (2013). kepemimpinan, motivasi, dan lingkungan kerja pengaruhnya terhadap kinerja karyawan pada kanwil ditjen kekayaan negara suluttenggo dan maluku utara di manado. Vol.1 No.4. Universitas Sam Ratulangi Manado.

Priyatno, Duwi. (2017). Panduan Praktis Olah Data Menggunakan SPSS. Yogyakarta: Andi

Putra, Danang Siaga. (2013). hubungan antara perceived organizational support dengan organizational citizenship behavior pada karyawan pt en seval putera megatrading divisi transportasi cabang sidoarjo. Vol.2 No.1.

Putra \& Rahyuda. (2016). pengaruh kompensasi, lingkungan kerja dan perceived organizational support (pos) terhadap retensi karyawan. Vol.5 No.2.

Putra \& Sriathi. (2017). pengaruh perceived organizational support dan komitmen organisasi terhadap organizational citizenship behavior. Vol.6 No.9. Universitas Udayana.

Sahrah, Alimatus. (2017). Perceived Organizational Support Dan Organizational Citizenship Behavior Pada Perawat Rumah Sakit. Vol.19 No.1. Universitas Mercu Buana Yogyakarta.

Sofyan, Diana Khairani. (2013). Pengaruh Lingkungan Kerja Terhadap Kinerja Kerja Pegawai BAPPEDA. Vol.2 No.2. Universitas Malikusaleh.

Sugiyono. (2014). Metode Penelitian Kuantitatif Kualitatif dan R\&D. Bandung: Alfabeta

Sukarjati, dkk. (2016). Pengaruh Kepemimpinan, Pengembangan Sumber Daya Manusia dan Kepuasan Kerja Terhadap Kinerja Pegawai Kantor Dinas Pengelolaan Keuangan dan Aset Daerah Kota Semarang. Vol.2 No.2. Fakultas Ekonomika dan Bisnis Universitas Pandanaran Semarang.

Susmiati \& Sudarma. (2015). Pengaruh Budaya Organisasi dan Dukungan Organisasi Persepsian Terhadap Kinerja Karyawan dengan Komitmen Organisasi Sebagai Variabel Intervening. Universitas Negeri Semarang.

Sutrisno, Edi. (2010). Budaya Organisasi. Jakarta: Kencana.

Kurniawan, H. (2019). HUBUNGAN ANTARA KONFLIK PERAN DAN AMBIGUITAS PERAN DENGAN KINERJA PERAWAT WANITA DI RSUD SUNGAI DAREH DHARMASRAYA. Psyche 165 Journal, 12(2), 124-133. 